\title{
Certeza jurídica y el problema de la nulidad de los contratos públicos en Chile
}

Gladys Camacho Cépeda ${ }^{2}$

\section{RESUMEN}

En ausencia en el derecho chileno de un régimen legal y de pautas que permitan resolver los conflictos que se presentan en materia de compras públicas, este artículo estudia los desarrollos jurisprudenciales y doctrinales sobre la aplicación de la institución de la nulidad a las compras públicas. Para ello, se parte de la conexión que existen entre la nulidad constitucional y la nulidad administrativa, nociones que están estrechamente ligadas en su formulación pero que, ante un desarrollo legislativo insuficiente, en su alcance no es clara aún una distinción desde sus consecuencias jurídicas. Se pasa luego a explicar cómo esto hace que en la práctica pueda terminar aplicándose, en materia de contratación pública, la institución de la invalidación del acto administrativo.

Palabras clave: contratación pública, nulidad del contrato, licitación pública, acción de nulidad de derecho público.

1 Siglas empleadas: CPR: Constitución Política de la República, LOCBGAE: Ley Orgánica Constitucional de Bases Generales de la Administración del Estado n. ${ }^{\circ}$ 18.575; LBPA: Ley n. ${ }^{\circ} 19.880$ Establece las Bases de los Procedimientos Administrativos que rigen los actos de los órganos de la Administración del Estado; NDP: nulidad de derecho público, TCP: Tribunal de la Contratación Pública.

2 Profesora Asociada de Derecho Administrativo, Universidad de Chile, Santiago, Chile. Doctora en Derecho de la Universidad Carlos III de Madrid, Madrid, España. Correo-e: gcamacho@derecho.uchile.cl. Enlace ORCID: 0000-0003-4196-2372. Fecha de recepción: 18 de agosto de 2020. Fecha de modificación: 10 de septiembre de 2020. Fecha de aceptación: 30 de septiembre de 2020. Para citar el artículo: CAMACHO CÉPEDA, GLADYs, "Certeza jurídica y el problema de la nulidad de los contratos públicos en Chile", Revista digital de Derecho Administrativo, Universidad Externado de Colombia, n. ${ }^{\circ} 25$, 2021, pp. 145-174. DOI: https://doi.org/10.18601/21452946.n25.05. 


\title{
Legal Certainty and the Conundrum of the Nullity of Public Contracts in Chile
}

\author{
ABSTRACT
}

In the absence of a legal regime and standards to solve issues pertaining to public procurement, this paper examines case-law and scholarly works on the application of the institution of nullity to public contracts. To this end, it starts by exploring the existing connection between the notions of constitutional nullity and administrative nullity. Though these notions are closely attached in their formulation, the distinction between their legal consequences is not yet clear. The article then explains how this and an insufficient legislative development can lead to the application of the institution of the voidance of the administrative act in the context of public procurement.

Keywords: Public Procurement, Nullity of Contracts, Public Bidding, Public Law Action of Nullity.

\section{INTRODUCCIÓN}

El legislador chileno ha tenido un sempiterno descuido para dotar de un marco normativo a instituciones administrativas que son clave para su buen funcionamiento y para la debida certeza jurídica de los administrados en sus relaciones con la Administración pública. Esto es precisamente lo que sucede con la contratación administrativa, ya que se carece de una ley general que fije sus principios y bases comunes, situación que debe solventarse con los principios generales del derecho y, en algunos casos, con leyes especiales que regulan tipologías contractuales específicas como son el contrato de obra pública, concesión de obra pública y suministro y servicios $^{3}$. Es de la falta de una regulación especial en el derecho chileno para las compras públicas que el estudio de la institución de la nulidad en materia de contratos estatales adquiere una mayor relevancia, sobre todo en lo que respecta a la satisfacción de las exigencias derivadas del principio de seguridad jurídica.

La carencia de una normativa general que oriente la actividad contractual de la Administración y, por el contrario, la existencia de regulaciones especiales aplicables a diferentes tipos de contratos públicos no permite reconocer criterios definidos que indiquen qué normas o reglas se deben aplicar

3 Contratos de obra pública (Reglamento para contratos de obra pública), concesión de obra pública (Decreto con fuerza de Ley n. ${ }^{\circ} 164$ de 1991, Decreto con fuerza de Ley 850 de 1997, DS MOP 900 de 1996, Reglamento DS 956 de 1997 y la Ley 19460, Ley 20.410), de suministros y de servicios (Ley 19.886). 
en relación al régimen de nulidad de los contratos de la Administración. En ausencia de un régimen legal para las compras públicas en el derecho chileno, es necesario comenzar el análisis de la institución de la nulidad del contrato público a partir de la normativa constitucional cuyo origen se encuentra en la defensa del Estado republicano, así como por la revisión de planteamientos doctrinales contrapuestos y de los desarrollos en la jurisprudencia administrativa ${ }^{4}$ y jurisdiccional alrededor de esta figura. Esto nos permitirá determinar luego cuál es la extensión del alcance de la institución de la nulidad al contrato público.

\section{LAS NOCIONES DE NULIDAD CONSTITUCIONAL Y NULIDAD ADMINISTRATIVA EN EL DERECHO CHILENO}

Reflexionar desde el derecho público sobre la institución de la nulidad en Chile nos remite al examen de la noción que desde la doctrina se ha llamado nulidad de derecho público (NDP) a partir del texto normativo contenido en el artículo 7 de la Constitución Política. El citado precepto estipula las pautas básicas que los órganos del Estado deben cumplir para que su actuación se repute válida. De forma especial, junto con el artículo 6 de la Carta Política, ambas disposiciones constituyen el principal respaldo normativo del principio de juridicidad de la Administración pública. No hay mayor discusión de que el desconocimiento de ese conjunto de pautas básicas constituye los fundamentos de la nulidad de la actuación administrativa en el derecho chileno. En contraste con esto, no es pacífico el debate sobre las consecuencias jurídicas que acarrean los vicios que se derivan del incumplimiento de las mismas. El artículo 7, inciso 3, de la Constitución Política solo emplea el concepto "nulo" y no el término nulidad de derecho público, pero un sector de la doctrina ha acuñado este concepto y así ha sido recogido, principalmente por los tribunales ordinarios 5 . Ahora bien, esta regla no es nueva, por lo que es conveniente formular brevemente sus antecedentes a fin de que aporten a una mejor comprensión e interpretación de las consecuencias de la aplicación de la nulidad en materia administrativa.

4 A la Contraloría General de la República como entidad fiscalizadora autónoma de los actos de la Administración del Estado, en virtud del artículo 7 de su Ley Orgánica Constitucional n. ${ }^{\circ} 10.336$, se le reconoce que solo sus decisiones y dictámenes emitidos en materias de su competencia "podrán hacerse valer como constitutivos de la jurisprudencia administrativa".

5 Eduardo Soto Kloss, "La regla de oro del derecho público chileno: sobre los orígenes históricos del artículo 160 de la Constitución de 1883", Anales de la Universidad de Cbile, n. ${ }^{\circ}$ 20, 1989, pp. 803-833. 
Los antecedentes de la mal llamada regla de oro, como algunos ${ }^{6}$ califican a esta disposición constitucional, se remontan a la Constitución de $1833^{[7]}$, que viene a sustituir a la Carta Política de 1828, cuya limitada eficacia fue la razón por la cual el nuevo texto, a instancias de Mariano Egaña, cuidó de introducir reforzamientos a su cumplimiento en dos direcciones en el capítulo XI de disposiciones generales: primero, con una disposición orientada a prohibir la representación popular fraudulenta (artículo $159^{[8]}$ ) y segundo, con una norma que buscaba evitar el ejercicio ilícito de poder o de derechos (artículo $160^{[9]}$ ).

El artículo 160 de la Constitución de 1833, que en la actual Carta constitucional se reproduce prácticamente igual en los incisos $2 .^{\circ}$ y $3 .^{\circ}$ del artículo 7 de la CPR (formando parte del capítulo I sobre las bases de la institucionalidad), tenía por objeto una finalidad política (la estabilidad del régimen constitucional en su conjunto $\left.{ }^{10}\right)$, más que constituirse en una norma adecuada para resolver controversias relacionadas con el correcto ejercicio de la gestión administrativa que formalmente se traduce en actos y contratos administrativos, lo que no necesariamente está conectado con la usurpación del poder ni supone intentos de socavar el Estado de derecho.

Hay que tener en cuenta que la Constitución de 1833 es la primera carta política que logra instituir la República de forma estable. Esta constitución se apoya en la autoridad que emana de la ley soberana en los términos portalianos, cuyo énfasis está en la legitimación del poder en virtud de la legalidad formal.

6 Véanse, por ejemplo, Gabriel Bocksang Hola, "El ámbito de aplicación de la nulidad de derecho público", en Juan Carlos Ferrada Bórquez (ed.), La nulidad de los actos administrativos en el derecho cbileno, Santiago de Chile: Legal Publishing-Thomson Reuters, 2013, pp. 49-75, y Juan Carlos Ferrada Bórquez, "Nuevas restricciones a la nulidad de derecho público como proceso administrativo: una jurisprudencia interesante, pero inconsistente", Anuario de Derecho Público, 2010, pp. 189-203.

7 Más aún, esta disposición se puede conectar con la frase final del artículo $3 .{ }^{\circ}$ de la Declaración de Derechos del Hombre y del Ciudadano de 1789, que expresando el espíritu republicano de la revolución ordena: "Ningún cuerpo ni ningún individuo pueden ejercer autoridad alguna que no emane expresamente de ella".

8 El artículo 159 de la Constitución de 1833 prescribe: "Ninguna persona ó reunion de personas puede tomar el título o representacion del pueblo, arrogarse sus derechos, ni hacer peticiones á su nombre. La infraccion de este artículo es sedicion".

9 El Artículo 160 de la Constitución de 1833 prescribe: "Ninguna magistratura, ninguna persona, ni reunion de personas pueden atribuirse, ni aún a pretesto de circunstancias estraordinarias, otra autoridad ó derechos que los que espresamente se les haya conferido por las leyes. Todo acto en contravención á este artículo es nulo"

10 Eduardo Soto Klos describe así los antecedentes históricos que rodearon esta carta política: "Las luchas intestinas no habían cesado y el principio de autoridad, tan necesario en la primera etapa de la vida republicana independiente [... ] se esfumó de modo muy notorio, al punto que la propia Constitución de 1828 era de un espíritu tan liberal que carecía la suprema autoridad ejecutiva de potestades para hacer frente a quienes se enfrentaran al poder del Estado". Eduardo Soto Kloss, La regla de oro del derecho público chileno. Estudios en bonor de Alamiro de Ávila Martel, Santiago: Anales Universidad de Chile, 1989, p. 805. 
Ello ocurre dos décadas antes que se dicte el Código Civil de Bello, en 1857, cuerpo legal que también se ocupa del instituto jurídico de la nulidad, pero en dos planos: como sanción a las contravenciones legales que mellan al Estado en su conjunto y rompen la armonía de su desarrollo (artículos 10 y 11 del Titulo Preliminar) y como instituto necesario para resolver los conflictos de los negocios jurídicos que exige el camino civilizador en el que se inserta el Código Civil (artículos 1.681 y ss.). Ciertamente, como un importante complemento de la Constitución de 1833, el Título Preliminar del Código Civil (compuesto por 53 artículos) cumple una relevante función en la construcción del Estado independiente ${ }^{11}$, pues en el proceso por sustituir la legislación antigua poco apropiada para el estatus independiente que se había logrado, se hace cargo de consignar una serie de reglas que están orientadas a sentar las bases del nuevo sistema jurídico que se pretendía erigir ${ }^{12}$.

Por lo que respecta a la nulidad, las referencias del Título Preliminar están consignadas en el apartado "3. Efectos de la ley", cuyo título es descriptivo de la naturaleza general de la materia que aborda. Dicho apartado trata, entre otros, de la regla general de irretroactividad de la ley y, particularmente, los artículos 10 y 11 que aquí interesan se refieren a la nulidad de los actos ${ }^{13}$. Estas disposiciones establecen que aquellos actos que contravengan las prohibiciones legales carecerán de valor, reforzando la obligatoriedad de la ley y por tanto la eficacia de las normas legales. Esto se asegura indicando que la declaración de nulidad no obsta para la aplicación de la ley aún cuando el acto anulado

11 Los artículos del Título Preliminar, entre otras materias, tratan acerca de la ley, su concepto, promulgación, su obligatoriedad, los efectos en el tiempo y el espacio, su derogación y su interpretación. Como se aprecia, todas estas materias son relevantes para el buen funcionamiento de la República.

12 De acuerdo con Guzmán, el nuevo orden de cosas que trajo consigo la independencia intentó reemplazar la legislación de la etapa colonial, pues "Resultaba, así, natural que los dirigentes de los nuevos Estados aplicaran la abstracta idea de emitir una nueva y completa legislación diseñada como código bajo la forma de una adopción o, al menos, de imitación del Code Civil". Alejandro Guzmán, "La influencia del Código Civil Francés en las codificaciones americanas", Cuadernos de Extensión Jurídica, n. ${ }^{\circ}$ 9, 2004, p. 24. Por su parte, también se destaca la relevancia que tiene el Código Civil en la construcción no solo del Estado chileno sino del conjunto de las jóvenes repúblicas americanas porque "fue, sin duda, el Código Civil Chileno de 1855, cuyo proyecto redactó muy minuciosamente Andrés Bello, el más influyente sobre la coetánea y ulterior codificación civil americana". Santiago Muñoz Machado, Vestigios, Madrid: Crítica, 2020, p. 326.

13 Los artículos citados prescriben: "Artículo 10. Los actos que prohíbe la ley son nulos y de ningún valor; salvo en cuanto designe expresamente otro efecto que el de nulidad para el caso de contravención".

"Artículo 11. Cuando la ley declara nulo algún acto, con el fin expreso o tácito de precaver un fraude, o de proveer a algún objeto de conveniencia pública o privada, no se dejará de aplicar la ley, aunque se pruebe que el acto que ella anula no ha sido fraudulento o contrario al fin de la ley". 
no haya sido fraudulento o contrario al fin contenido en la misma ${ }^{14}$. Al mismo tiempo, estas reglas admiten que la contravención a la ley no siempre conlleve la nulidad radical de pleno derecho cuando el ordenamiento haya designado expresamente otro efecto. Además, dichos preceptos deben leerse en conjunto con el artículo 1462 del mismo código, que dispone que hay objeto ilícito en todo lo que contraviene el derecho público chileno, y el artículo 1681 que sanciona la ilegalidad de un acto en los siguientes términos: "Es nulo todo acto o contrato a[1] que [le] falta alguno de los requisitos que la ley prescribe para el valor del mismo acto o contrato, según su especie y la calidad o estado de las partes", estableciendo que "La nulidad puede ser absoluta o relativa", por lo que la determinación de cuándo aplicar una u otra es materia que el legislador deberá señalar.

Es importante destacar que la Constitución de 1925 reprodujo en sus artículos 3 y 4 exactamente los mismos textos de los artículos 159 y 160 de su predecesora, pero trasladándolos al capítulo I sobre Estado, gobierno y soberanía. Dicho precepto está destinado fundamentalmente a cautelar la representatividad que se exige de un Estado democrático cuya soberanía, aunque radicada esencialmente en la nación, se ejerce por las autoridades que la Constitución reconoce (artículo 2 de la Constitución de 1925). Hasta aquí, entonces, fluye claramente que el precepto hoy contenido en los incisos $2 .{ }^{\circ}$ y $3 .^{\circ}$ del artículo 7 de la $\mathrm{CPR}^{15}$ buscaba sobre todo ser un garante del orden constitucional in toto, mas no servir como una categoría para resolver conflictos jurídicos ordinarios derivados de la gestión de los poderes públicos legislativo, judicial o gubernamental (fundamentalmente administrativa). En este caso, lo que se sanciona es el abuso (de cualquier magistratura del Estado) y la usurpación (por cualquier persona o grupo de personas) de la autoridad que se les ha conferido a las primeras o de que carecen las segundas. En resumen, se previene ese ilegítimo ejercicio de poder o de derechos que no están amparados en la Constitución o las leyes.

Por consiguiente, ante la ausencia de una regulación especial sobre tan importante tema práctico ${ }^{16} \mathrm{y}$ ante la resistencia de aplicar el régimen privado

14 Claudia Bahamondes, "La nulidad de los actos administrativos y la nulidad de los actos y contratos del Código Civil: ¿son tan distintas?", Revista Chilena de Derecho Privado, n. ${ }^{\circ} 8$, 2007, pp. 70-71.

15 El artículo 7 la CPR preceptúa: "Los órganos del Estado actúan válidamente previa investidura regular de sus integrantes, dentro de su competencia y en la forma que prescriba la ley. Ninguna magistratura, ninguna persona ni grupo de personas pueden atribuirse, ni aun a pretexto de circunstancias extraordinarias, otra autoridad o derechos que los que expresamente se les hayan conferido en virtud de la Constitución o las leyes. Todo acto en contravención a este artículo es nulo y originará las responsabilidades y sanciones que la ley señale".

16 Concha afirma que un problema de base en relación con la nulidad del derecho público es que el derecho chileno no "ha establecido a nivel legislativo una reglamentación acabada 
contenido en el Código Civil ${ }^{17}$, la doctrina se avocó a construir, en primer lugar, el singular instituto que se conoce como nulidad de derecho público $(\mathrm{NDP})^{18}$ y, en segundo lugar, la acción constitucional de nulidad de derecho público $^{19}$. La situación cobra una mayor complejidad por cuanto la Constitución de 1980 añade un primer inciso a la norma que se había formulado en 1833 (replicado en la de 1925). Este añadido es el inciso 1. ${ }^{\circ}$ del artículo 7 de la $C P R$, en el cual se consignan tres exigencias para la actuación válida de los órganos del Estado, por lo que la sanción de nulidad que se contempla en el inciso $3 .^{\circ}$ de dicho precepto es aplicable tanto para la infracción del inciso $1 .{ }^{\circ}$ como del inciso $2 .^{\circ}$. La pregunta que cabe hacerse es si este inciso $1 .^{\circ}$ cambia la función de garante del ordenamiento constitucional que venía cumpliendo este precepto en las Constituciones de 1833 y de 1925. Al parecer, la respuesta es afirmativa, pero esta opción del constituyente padece de un defecto y es que requiere que el legislador, tal como invoca en su parte final el artículo 7 de la CPR, determine las consecuencias jurídicas de la infracción.

La NDP, según unánime parecer de la jurisprudencia y la doctrina, procede cuando se infringe alguna de las tres exigencias básicas para la validez de las actuaciones de los órganos estatales contenidas en el inciso $1 .{ }^{\circ}$ del artículo 7 de la $\mathrm{CPR}$, las cuales se refieren a que estas deben actuar contando con previa investidura regular, en el marco de su competencia y en la forma que prescriba la ley. Requisitos todos que atienden a aspectos formales y no al fondo de la decisión de la autoridad. Siendo esto así, aún para aquellas autoridades que están contempladas en la Constitución, el contenido de la ley es fundamental para desarrollar y precisar los vicios señalados por esta norma constitucional y, por tanto, la NDP siempre será una sanción a la violación de la ley, pues será esta la que, en definitiva, deberá precisar: a) cuándo una autoridad adquiere la

para [la] nulidad de derecho público". RiCARDO CONCHA, "El desarrollo del régimen jurídico de la nulidad de derecho público", Revista de Derecho, vol. XXVI, n. ${ }^{\circ}$ 2, 2013, p. 94. Bahamondes concluye en su trabajo: "La nulidad de los actos administrativos no tiene un régimen explícito en el ámbito del derecho administrativo", Claudia BaHamondes, "La nulidad de los actos administrativos...", óp. cit., p. 102.

17 En la doctrina publicista, el primero que abordó la problemática e intentó construir una dogmática de la nulidad contemplada en la Constitución autónoma de aquella que regula el derecho civil fue Mario Bernaschina, de quien se afirma: "Dicho catedrático ha propiciado que la nulidad de los actos emanados de los órganos estatales es de carácter especial, que no puede ser considerada en la misma forma que la nulidad civil". JORGE REYES, "Reflexiones acerca de la nulidad de derecho público", Revista de Derecho, n. ${ }^{\circ} 4,1993$, pp. 91-126. Disponible en: http://revistas.uach.cl/html/revider/v4/body/art07.htm [consultado el 31 de julio de 2020].

18 Es pionero en este afán el profesor Mario Bernaschina y le siguieron discrepando con él o profundizando su planteamiento los profesores Enrique Silva Cimma, Eduardo Soto Kloss y Pedro Pierry, entre otros.

19 En esta tarea destaca Gustavo Fiamma, "Acción constitucional de nulidad y legitimación activa objetiva", Revista de Derecho Público, n. ${ }^{\circ} 49,1991$, pp. 91-99. 
investidura pública ${ }_{i}$ b) cuál es el ámbito competencial de los distintos órganos; y c) la formalidad (procedimiento administrativo, judicial, etc.) que deberá cumplirse. Nótese además que el inciso 2 del artículo 7 de la CPR no solo aplica a las autoridades sino también a particulares cuando estos pretendan ejercer derechos ilegítimamente, pues está prohibido constitucionalmente atribuirse otros "derechos que los que expresamente se les hayan conferido en virtud de la Constitución o las leyes".

Ahora bien, sobre lo que no hay absolutamente consenso en la doctrina ni en la jurisprudencia es sobre los efectos que la infracción de los incisos 1 y 2 del artículo 7 de la CPR producen cuando el inciso $3 .^{\circ}$ del mismo precepto emplea la fórmula "Todo acto en contravención a este artículo es nulo y originará las responsabilidades y sanciones que la ley señale". ¿Se refiere a la nulidad absoluta o de pleno derecho insanable?, irequiere ser declarada?, ¿prescribe o es perpetua?, ¿sus efectos son ex tunc o ex nunc? Las respuestas que ha dado la doctrina son ampliamente conocidas en uno y otro sentido. Es decir, un amplio sector ${ }^{20}$ sostiene que en el artículo 7 de la CPR se encuentran las causales de NDP que operan ab initio e ipso iure, que es insanable e imprescriptible, que se aplica a todo acto estatal, que es de regulación constitucional y que, además, no requiere que sea declarada por ninguna magistratura, afirmaciones todas que acercan la NDP a la inexistencia del acto (o contrato). De otro lado, también un importante sector doctrinal ${ }^{21}$ refuta dichos efectos, en concreto, que opere sin necesidad que sea declarada y que siempre opere de pleno derecho y sea insanable. Por el contrario, en los diversos desarrollos que este sector doctrinal ha realizado encontramos que se sostiene que el acto existe hasta la declaración de nulidad, que no siempre se trata de nulidad de pleno derecho, que es el legislador el que debe definir las sanciones con las que se castigará la infracción de la juridicidad y que la nulidad, aun cuando sea absoluta, prescribe por exigencias de los principios de certeza y seguridad jurídica. En relación

20 Véanse Eduardo Soto Kloss, La regla de oro del derecho..., óp. cit., pp. 803-833; “La nulidad de derecho público en el derecho chileno", Revista de Derecho Público, n. ${ }^{\circ} 47 / 48,1990$, pp. 11-25; y "La nulidad de derecho público: su actualidad", Revista de Derecho de la Universidad Católica de Valparaíso, n. ${ }^{\circ}$ XVII, 1997, pp. 347-355; Mario BernasChInA, "Bases jurisprudenciales para una teoría de las nulidades administrativas", Boletín del Seminario de Derecho Público, n. ${ }^{\circ}$ 45-48, 1949, pp. 548-559; y IVÁN ARÓSTICA MALDONADO, "¿Qué queda de la 'presunción de legalidad'?", Revista de Derecho y Jurisprudencia, t. LXXXVIII, n. ${ }^{\circ} 1$, 1991, pp. 1-7. Más recientemente, Gabriel BockSAnG, "De la imprescriptibilidad de la nulidad de derecho público", Ius Publicum, n. ${ }^{\circ} 14,2005$, pp. 87-104

21 Véanse Pedro Pierry Arrau, "Nulidad en el derecho administrativo", Revista de Derecho de la Universidad Católica de Valparaíso, n. ${ }^{\circ}$ XV, 1993-1994, pp. 79-100; JORGE ReYes Riveros, La nulidad de derecho público, Santiago: Editorial Conosur, 2000; Jaime Jara Schnettler, La mulidad de derecho ante la doctrina y la jurisprudencia, Santiago: Editorial Libro Mar, 2000; SALVADOR Mohor Abuauad, "Acerca de la nulidad de derecho público en nuestro sistema jurídico constitucional y, en especial, de la interpretación armónica de los artículos $6 .^{\circ}$ y $7 .^{\circ}$ de la Constitución", Revista de Derecho Público, n. ${ }^{\circ}$ 76, 2014, pp. 317-327. 
con la prescripción, si bien los tribunales ordinarios inicialmente acogieron la doctrina y el concepto de nulidad de derecho público de pleno derecho y su imprescriptibilidad ${ }^{22}$, la jurisprudencia se ha ido permeando de la crítica formulada a esta teoría y acogiendo una serie de distinciones que se expresan en la jurisprudencia. De este modo, se distingue entre la nulidad propia, que afecta al acto, y la prescripción de la acción de nulidad, que es la que impide que este pueda ser cuestionado eternamente ${ }^{23}$.

Por lo que respecta a la acción de nulidad de derecho público, cuya construcción es doctrinal y jurisprudencial, esta última la ha ido colocando en un lugar subsidiario de las acciones contencioso administrativas especiales que

22 En la sentencia de la Corte Suprema, caso Pérsico Paris contra Fisco, Rol 2469-94, se sostuvo: "Que tratándose en la especie de una nulidad de derecho público, en la que se implican no solo el interés privado del actor sino también el de la sociedad, en cuanto las actuaciones de los poderes públicos no pueden transgredir el Estado de derecho, forzoso es admitir que las reglas del derecho común no pueden tener aplicación sino cuando las normas del derecho público se remitan a ellas o cuando la naturaleza de la institución admita que el derecho público se integre con normas comunes; y en la especie indudablemente no corresponde esta integración cuando de lo que se trata es de sancionar la posible omisión en que habría incurrido el actor al demorar el inicio de este juicio, porque para alcanzar semejante efecto se requeriría de una expresa remisión a las normas del derecho común que permitieran privar de la acción de nulidad de derecho público por el transcurso de un cierto lapso, lo que por otra parte exigiría admitir que los actos que contravienen el artículo $7 .^{\circ}$ de la Constitución Política de la República pudieran purgarse del vicio que los aqueja al cabo de cierto término, lo que pugna con el propio tenor del precepto citado en cuanto señala que tales actos son nulos y originan las responsabilidades y sanciones que la ley señale, dando a los vicios fundantes de tal nulidad una entidad tal que impide que el solo transcurso del tiempo pueda sanear de ellos al acto que los contiene; en consecuencia, no existiendo en el derecho público una norma que declare prescriptible la acción ejercida de estos autos, ni otra similar al artículo 1683 del Código Civil que priva de la acción de nulidad absoluta común por saneamiento del acto en razón del transcurso de 10 años, no cabe extender analógicamente el alcance de los artículos 2515 y 2520 a un caso en que la naturaleza de los hechos guarda cierta semejanza con aquellos previstos en las normas citadas, pues ello importaría que los jueces hubiesen creado la norma por la cual se sancionaría al actor, circunstancia que conduce inevitablemente al rechazo de este capítulo de la nulidad". En el mismo sentido la sentencia de la Corte Suprema de 12 de agosto de 1998, caso Baltra Moreno con Fisco.

23 El legislador para paliar la ausencia de una jurisdicción administrativa general ha creado un gran número de acciones contencioso administrativas fundadas en la ilegalidad del acto. Tal es el caso del reclamo de ilegalidad municipal del artículo 151 de la LOCM; $_{\text {e }}$ reclamo de ilegalidad de los gobiernos regionales del artículo 108 de la LOCGAR, entre otros, la particularidad es que para accionar estos reclamos se ha de sujetarse, en especial, a un plazo bastante breve. La segunda vía de mitigación de la ausencia aludida ha sido la creación de tribunales especiales que conocen de reclamos por ilegalidad de ciertos actos administrativos, este es el caso, entre otros, del Tribunal de Compras Públicas respecto de los actos administrativos adoptados entre el llamado a la licitación y la adjudicación, los tribunales ambientales, que conocen de los reclamos por ilegalidad de los actos administrativos emanados en el marco del sistema de evaluación ambiental y de los instrumentos de gestión ambiental contenidos en la Ley 19.300. 
se conocen por los tribunales ordinarios y los tribunales administrativos especiales ${ }^{24}$. Pero más aún, la jurisprudencia ha identificado que bajo la acción de NDP, en realidad se encubren dos acciones de distinta naturaleza, lo cual tiene efectos en relación a la aplicación del instituto de la prescripción. De un lado, la acción encaminada a obtener la nulidad de un acto administrativo resulta imprescriptible y, de otro lado, la acción que busca el reconocimiento de un derecho, usualmente de contenido patrimonial, como consecuencia de que la nulidad sea acogida, se entiende que prescribe de acuerdo con las reglas generales contenidas en las disposiciones de los artículos $2.497,2.514$ y 2.515 del Código Civil ${ }^{25}$. Con esta interpretación, se le resta el interés que reviste intentar esta acción ordinaria de nulidad.

No hace parte del objeto de estudio de la presente investigación detenernos en reconstruir todo el debate doctrinal a este respecto, pues nuestro objetivo es analizar cómo ha operado el sistema de nulidad en el ámbito de la contratación y si es posible construir sobre estos elementos algunas bases para un sistema de nulidades propia del ordenamiento administrativo que atienda a las singularidades que este tiene. Para ello, para finalizar este apartado, es necesario realizar una breve referencia a cómo operan los vicios de nulidad señalados en el inciso $1 .^{\circ}$ del artículo 7 de la CPR.

Como una premisa básica de la interpretación del inciso $3 .^{\circ}$ del artículo 7 de la CPR de la que se debe partir es que bajo el concepto nulo no solo cabe la nulidad absoluta sino también la nulidad relativa, que son categorías generales y no exclusivas del derecho privado. Por tanto, ya que el constituyente no se hizo cargo de aclarar si se refería solo a la primera y no dejaba opción a que se pudiera referir a la segunda, es imperativo que el legislador desarrolle dicho precepto de forma coherente con la función que la Constitución le da a este instituto. Ahora bien, lo que sí tienen en común ambos conceptos (la

24 Véase la sentencia de la Corte Suprema recaída en la causa Rol n. ${ }^{\circ}$ 3.745-2005, que reprocha que el actor no haya ejercido oportunamente su derecho a reclamo mediante la acción contenciosa especial ya que ello no puede subsanarse mediante la acción de NDP. En el mismo sentido, véase la sentencia de la Corte Suprema recaída en la causa Rol n. ${ }^{\circ} 34.277$ 2017, que afirma: "La denominada 'acción de nulidad de derecho público' por la doctrina y aceptada por la jurisprudencia, es entonces, toda acción contencioso-administrativa encaminada a obtener, por parte de un tribunal de la República, la anulación de un acto administrativo [...]. Cuando existe una acción contenciosa administrativa 'de nulidad de derecho público"' contemplada en la ley, se aplica ésta y con el procedimiento allí establecido, y no otra. Sin embargo, si la ley no contempla ningún procedimiento o acción especial para impugnar el acto administrativo solicitando su anulación, se puede utilizar el procedimiento del juicio ordinario" (considerando décimo).

25 Eduardo Cordero Quinzacara, "Nulidad de derecho público y prescripción", Mercurio Legal 23 de abril de 2013. Disponible en: https://www.elmercurio.com/Legal/Noticias/AnalisisJuridico/2013/04/23/Nulidad-de-Derecho-Publico-y-Prescripcion.aspx\#: :text=Desde\%20 su\%20formulaci\%C3\%B3n\%20inicial\%2C\%20se,una\%20regla\%20en\%20tal\%20sentido [consultado el 13 de agosto de 2020]. 
nulidad absoluta y la nulidad relativa) es que están ligados a una infracción del ordenamiento jurídico y son las consecuencias jurídicas de este incumplimiento las que corresponde precisar al legislador, pues hasta el momento se ha mantenido en fórmulas principistas y generales. De ello, tenemos al menos dos ejemplos, uno primero en el artículo 2 de la LOCBGAE que recoge el espíritu del artículo 7, pero que deja claro que corresponde a la ley ordinaria definir las consecuencias jurídicas de esta infracción a la juridicidad. Así, ordena que

Los órganos de la Administración del Estado someterán su acción a la Constitución y a las leyes. Deberán actuar dentro de su competencia y no tendrán más atribuciones que las que expresamente les haya conferido el ordenamiento jurídico. Todo abuso o exceso en el ejercicio de sus potestades dará lugar a las acciones y recursos correspondientes.

Con esto aclara que el vicio de competencia en el actuar administrativo no solo comprende el "exceso de poder" sino la "desviación de poder", superando una interpretación formalista del precepto optando por su interpretación finalista que cautela con más efectividad el interés general al que debe responder toda actuación administrativa.

La segunda precisión que el legislador ha realizado en relación con la tercera causal que menciona el citado inciso $3 .^{\circ}$ del artículo 7 de la CPR está referida a las formalidades legales, esto es, procedimentales que se deben observar en el ámbito procesal (ya sea civil, penal, de familia, etc.), legislativo y de control constitucional, materias en las que el legislador ha cuidado de establecer los recursos y consecuencias jurídicas de las contravenciones al ordenamiento, por lo que la regla de la nulidad absoluta no se aplica ipso iure. No obstante, en el ámbito del procedimiento administrativo, a pesar de que es el que más afecta a los ciudadanos, hay un gran retraso en dotar de las normas necesarias y suficientes que permitan reconocer un sistema claro de nulidades administrativas, salvo los dos pasos que desde que se emprendió el proceso de retorno a la democracia se han producido, pero que son a todas luces insuficientes. De este modo, en 1989, al reformarse el artículo 38 de la Constitución Política ${ }^{26}$, se buscó evitar la indefensión que habían sufrido los administrados durante la vigencia de la Constitución de 1925, por cuanto los tribunales ordinarios se declaraban incompetentes de conocer acciones de nulidad de actos administrativos, porque de acuerdo con la citada Constitución, esta materia correspondía a los tribunales administrativos que se debían constituir, pero nunca se hizo por el legislador. Ello no hace sino rebelar que la nulidad radical ipso iure como un buen sector de la doctrina sigue postulando no ha operado así. El segundo paso lo dio el legislador en 2003, con la Ley 19.880 (LBPA) que

26 La Ley de Reforma Constitucional n. ${ }^{\circ} 18.825$, eliminó del inciso $2 .^{\circ}$ del artículo 38 de la CPR la frase "tribunales contenciosos administrativos". 
contiene las bases del procedimiento administrativo. En dicho texto legal se zanjó la discusión sobre la capacidad de la propia Administración de invalidar sus actos, reconociendo esta facultad en el artículo 53, además permitió que la invalidación pueda ser total o parcial, y estableció un plazo de dos años dentro del cual esta facultad administrativa puede ejercerse. Sin embargo, la LBPA perdió la oportunidad para regular el sistema de invalidación administrativa, institución fundamental para la correcta operatoria del acto administrativo.

Con todo, nulidad e invalidación en nuestro ordenamiento son dos categorías equivalentes y así lo confirma el empleo indistinto que hace el artículo 7 de la CPR, el cual inicia su texto con la frase "Los órganos del Estado actúan válidamente" y termina concluyendo con "Todo acto en contravención [...] es nulo". Por tanto, no es posible afirmar que los efectos jurídicos de la invalidación o de la nulidad de un acto administrativo sean dispares. La diferencia que tanto el legislador como la jurisprudencia judicial suelen hacer en el uso de estos conceptos tiene relación con el órgano que aplica la sanción ${ }^{27}$. Así, en los textos legales y en las sentencias se emplea el término nulidad si el órgano que la declara es judicial o invalidación si el órgano es de naturaleza administrativa (artículo 53 de la LBPA).

A diferencia del sistema español, el ordenamiento administrativo nacional no distingue entre nulidad y anulabilidad, sino solo entre nulidad total o parcial del acto administrativo (artículo 53 de la LBPA). Igualmente, no hay limitación para la legitimación activa del solicitante de la nulidad en razón de si lo que alega el afectado es un derecho o un interés, pues la mera afectación a alguno de estos en virtud de un acto inválido es lo que permite reconocer la legitimación del interesado para incoarla. Por último, el legislador tampoco resuelve sobre los efectos en el tiempo (ex tunc o ex nunc) de la declaración de nulidad o de la decisión invalidatoria, eso se deberá resolver caso a caso por la autoridad llamada a resolver, lo que se ha realizado empleando diversos principios generales (como la buena fe) o conceptos jurídicos indeterminados (tales como el interés común o general, derechos adquiridos).

La facultad de la autoridad administrativa de invalidar es una potestad discrecional amplia que se expresa en la decisión unilateral de acoger o rechazar la petición de iniciar un procedimiento de invalidación o bien de oficio iniciar la tramitación de un procedimiento invalidatorio, con la única limitante temporal de los dos años para ejercer esta atribución. Por consiguiente, la invalidación total o parcial del acto administrativo no depende tanto de si la

27 Esta antigua práctica se conecta con el acuerdo adoptado por los administrativistas uruguayos y chilenos en las Segundas Jornadas Chileno-Uruguayas de Derecho Comparado reunidas en Santiago en 1957, en el que, por razones de precisión jurídica, se reservó la voz nulidad para denotar la extinción de un acto administrativo resuelta por la autoridad judicial. Desde entonces, la doctrina y jurisprudencia ius administrativista ha mantenido esta distinción terminológica. 
infracción al ordenamiento jurídico es grave o no, sino del criterio, motivado sí, de la autoridad.

Si se examinan las causales de nulidad contempladas en el inciso $1 .^{\circ}$ del artículo 7 de la CPR se puede determinar que ni siquiera en relación con la primera de ellas, referida a la ausencia de "previa investidura regular", estamos siempre en presencia de una nulidad de pleno derecho o ipso iure, pues si bien el ordenamiento debiera reprochar la conservación o la convalidación de un acto administrativo dictado por una persona ajena a la organización pública, por ejemplo, el acto de una autoridad cuyo nombramiento sea declarado inválido, esta circunstancia no puede penalizar a quien con buena fe ha obtenido un pronunciamiento favorable. Esta opción se refuerza con la presunción de legalidad de la que goza el acto administrativo (inciso $8 .^{\circ}$ del artículo 3 de la LBPA) que le hacen reconocible como un instrumento jurídico de intervención que tiene un poder reconocido por el ordenamiento. Así lo refrenda el artículo 63 de la LOCBGAE, que expresamente estipula "La nulidad del nombramiento en ningún caso afectará la validez de los actos realizados entre su designación y la fecha en que quede firme la declaración de nulidad". Por tanto, aún cuando la autoridad administrativa pueda carecer de investidura regular y, en consecuencia, no poseer un elemento esencial para que se reconozca la eficacia de su decisión, ella no es nula ipso iure, lo que está fundado en la seguridad jurídica, la no afectación de la buena fe de los administrados, pero también en la eficacia y eficiencia de la Administración. La nulidad radical podría operar con seguridad en el caso de que estemos frente a una situación de usurpación de funciones públicas que el Código Penal castiga en el artículo 412, pero antes de estar en esa situación extrema hay un gran número de actos que pueden calificarse de irregulares, pero que siguen siendo válidos.

A su vez, la segunda causal de invalidación que contempla el citado inciso, referida a la infracción del deber de actuar "dentro de su competencia", tampoco deja claro si el ordenamiento sanciona esta causal con la nulidad radical de pleno derecho, pues según el caso, la falta puede ser consecuencia de la infracción al principio de jerarquía ${ }^{28}$, en cuyo presupuesto, la institución de la convalidación podría entrar en juego y así el acto podría quedar regularizado (el vicio se habría subsanado) y ser plenamente eficaz, y en otros puede ser un error en la competencia, situación en la que la invalidez debe necesariamente operar ${ }^{29}$. De acuerdo con el artículo 13 de la LBPA que, sin mencionarlo expresamente, conecta con el principio de conservación del acto, habilita a

28 Recordemos que las competencias se encuentran distribuidas con arreglo a los siguientes criterios: el territorio, la materia y el grado o nivel jerárquico.

29 A este respecto, ver el Dictamen n. ${ }^{\circ} 33.085 / 2013$, que concluye: "como se puede advertir la aplicación de multas por quien no estaba facultado para ello, no es una mera irregularidad procedimental o de forma, implicando un vicio que afectó la validez del acto por el cual se impuso la referida sanción contractual, [... ] razón por la cual, la Municipalidad 
la Administración a "subsanar los vicios de que adolezcan los actos que emita, siempre que con ello no se afectaren intereses de terceros". De igual forma, la invalidación del acto por contravención a la competencia puede producirse por inobservancia a los criterios territorial o material con el que se haya distribuido la facultad de la que el acto administrativo es expresión.

La tercera causal es la que más dudas propone sobre el supuesto efecto de nulidad absoluta que según un sector de la doctrina impone lo prescrito en el artículo 7 de la CPR, pues dicho precepto exige para la validez de una actuación de un órgano del Estado que este cumpla con "la forma que prescriba la ley" y eso, en el caso de los actos administrativos, nos remite al procedimiento administrativo que concretiza el principio de legalidad al que está sometida la Administración del Estado. Procedimiento que de acuerdo con la LBPA se rige por los principios de no formalización (artículo 13), razón por la que el legislador admite que los vicios de procedimiento o de forma no afecta la validez del acto administrativo, salvo que recaiga en algún requisito esencial del mismo, bien sea "por su naturaleza o por mandato del Ordenamiento y genera perjuicio al interesado".

Por tanto, la normativa legal y la aplicación práctica relacionada con los vicios del inciso $1 .{ }^{\circ}$ del artículo 7 de la CPR permiten concluir que la sanción de nulidad en el sentido de invalidez de pleno derecho no es, en principio, la regla general, sino que viene correspondiendo al legislador y a la jurisprudencia $^{30}$ señalar las sanciones que correspondan aplicar a la infracción de la norma citada de acuerdo con la parte final del inciso $3 .^{\circ}$ del mismo precepto ${ }^{31}$. Esta interpretación ha permitido armonizar el instituto de nulidad con principios fundamentales del ordenamiento jurídico como el de seguridad jurídica, la

de Coyhaique deberá invalidar tal decisión, procediendo a dictar el acto que en derecho corresponda, por el funcionario facultado al efecto".

30 En Dictamen n. ${ }^{\circ} 33.010 / 2015$, se pronuncia: "es útil considerar que la determinación de si los efectos de un acto que adolece de un vicio, configuran una situación consolidada o lesionan los derechos de terceros, de manera que ellos puedan ser protegidos, es un asunto casuístico toda vez que debe ponderarse caso a caso la magnitud de tales consecuencias, la clase de acto administrativo, la naturaleza de la causal para invalidar y otras circunstancias particulares, lo que impide emitir a priori juicios genéricos sobre cuál interés debe protegerse ante la concurrencia de dichos vicios".

31 En la sentencia de 2 de julio de 2019, recaída en causa Rol n. ${ }^{\circ}$ 29.094-2018, la Corte Suprema concluye que la ilegalidad de un acto administrativo, que puede acarrear su anulación, puede referirse a las circunstancias señaladas en el inciso $1 .^{\circ}$ del artículo 7 de la CPR, pero al mismo tiempo señala que: "no está demás señalar que no toda ilegalidad de un acto administrativo lleva aparejada su nulidad, por cuanto uno de los dogmas que informan la nulidad de derecho público es el de conservación, cuyo fundamento radica en que, revistiendo la nulidad el carácter de remedio excepcional frente a la ilegalidad de un acto administrativo, sólo será procedente si el vicio es grave y esencial". Apoyándose en otros principios generales como la confianza legítima, seguridad jurídica, derechos adquiridos y la buena fe, la Corte afirma que: "no cualquier irregularidad o defecto justifica la declaración de nulidad, sino cuando dicha anomalía atropelle las garantías de los administrados" (considerando décimo octavo). 
presunción de legalidad de los actos administrativos, la conservación de los actos, la buena fe y el de confianza legítima, pero también los de eficacia y eficiencia administrativas. Por su parte, el legislador, en concordancia con estos principios, ha determinado que la sanción de nulidad por la infracción a la juridicidad es la excepción. A modo de ejemplo, en el inciso $2 .^{\circ}$ del artículo 13 de la LBPA se ha determinado que los vicios de procedimiento o de forma no afectan la validez del acto administrativo, salvo que recaiga en un algún requisito esencial del mismo, sea por su naturaleza o por mandato del ordenamiento jurídico, y genere perjuicio al interesado ${ }^{32}$ reconociéndose la facultad de la Administración para subsanar los vicios de que adolezcan sus actos (inciso $3 .^{\circ}$, artículo 13 de la LBPA) $)^{33}$. La escasa normativa, así como su insuficiente densidad, producen que tanto los órganos de la Administración como los órganos de control de su acción (en sede administrativa como jurisdiccional) resuelvan con gran discrecionalidad los reclamos de ilegalidad.

\section{LA NULIDAD EN LA ETAPA PRECONTRACTUAL Y EN LA ETAPA DE EJECUCIÓN DEL CONTRATO}

Es compleja la problemática que suscitan las escasas normas de rango constitucional y legal que tenemos en el ordenamiento nacional en relación con aspectos importantes del régimen jurídico de los actos administrativos que, en especial, determinan el funcionamiento del instituto de nulidad en la actividad contractual. En particular, la Ley n. ${ }^{\circ} 19.880$ (LBPA) que estaba llamada a resolver aspectos críticos para un mejor funcionamiento de este instituto no regula los

32 En la jurisprudencia administrativa se sostiene el criterio que: "de acuerdo con lo informado reiteradamente por esta Contraloría General [...], en virtud de lo dispuesto en los artículos $6 .^{\circ}$ y $7 .{ }^{\circ}$ de la Constitución Política de la República y $2 .^{\circ}$ de la Ley n. ${ }^{\circ} 18.575$, que consagran el principio de juridicidad, en relación con el artículo 53 de la citada Ley n. ${ }^{\circ}$ 19.880, una vez que el SENAME, al estudiar los recursos administrativos señalados o actuando de oficio, constate la existencia de un vicio en el respectivo acto administrativo de adjudicación, se encuentra en el imperativo de invalidarlo, lo cual debe hacer en los términos del referido artículo 53, con el propósito de restablecer el orden jurídico quebrantado por una decisión contraria a derecho. Añade esa jurisprudencia que lo anterior procede en tanto que con esa medida no se lesionen los derechos adquiridos por terceros o se afecten situaciones consolidadas" (Dictamen n. $\left.{ }^{\circ} 33.010 / 2015\right)$. En el mismo sentido, véanse los dictámenes $\mathrm{n} .{ }^{\circ} 46.234$ de $2001, \mathrm{n} .{ }^{\circ} 80.286$ de 2012 y n. ${ }^{\circ} 74.850$ de 2013 , entre otros.

33 Lo que atendiendo a la presunción de legalidad de los actos administrativos permite afirmar a Dorn que el principio de trascendencia y conservación prevalecen cuando no existe perjuicio al derecho o interés de un tercero. De este modo, "la operatividad de pleno derecho de la nulidad obsta la ratio de la referida presunción [de legalidad] tornándola en una mera declaración lírica" por lo que "las ilegalidades del acto inocuas para el interesado no causan nulidad". Carlos Garrido Dorn, "Ley de Bases de Procedimiento Administrativo y Nulidad de Derecho Público", Revista de Derecho, n. ${ }^{\circ}$ 17, 2007, p. 13. 
elementos o requisitos de los actos, y respecto de la invalidez lo hace sin ningún rigor técnico, pues no distingue ni determina grados de invalidez $z^{34}$. Por ende, recae en la jurisprudencia administrativa y jurisdiccional la determinación en los casos concretos de cuando el vicio es insanable y deberá sancionarse con la nulidad de pleno derecho o cuando el vicio puede ser subsanado por Administración, o incluso cuando la Administración debe tolerar un acto viciado que padezca de ilegalidad si este afecta derechos o intereses de las personas ${ }^{35}$.

Al carecer de una ley general de la contratación pública que nos proporcione pautas generales para esta actividad, es la jurisprudencia la que nos ayuda a esclarecer aspectos básicos referidos al marco regulador de la contratación administrativa. De esta manera, se ha estabilizado un criterio en la jurisprudencia judicial afirmándose que el marco regulatorio del contrato público se compone por sus estipulaciones, las normas legales y reglamentarias que lo regulan, las bases de licitación, la oferta adjudicada y por las demás prescripciones técnicas ${ }^{36}$. Para los contratos de suministros y de servicios sometidos a la Ley n. ${ }^{\circ} 19.886$, el artículo $1 .^{\circ}$ establece que estos "se ajustarán a las normas y principios del presente cuerpo legal y de su reglamentación. En forma supletoria, se les aplicarán las normas de derecho público y, en defecto de aquellas, las normas del derecho privado", con ello se dispone una prelación taxativa cuya principal virtud es normalizar la aplicación de las disposiciones del derecho privado en la materia contractual que comprende no solo la etapa precontractual sino también de ejecución y desarrollo del contrato. Ciertamente, la jurisprudencia administrativa y jurisdiccional en todo lo no regulado por las leyes especiales de cada contrato aplica las normas del Código Civil, particularmente, en la interpretación de sus cláusulas.

34 Al referirse al capítulo IV de la LBPA, González Pérez formula un juicio contundente: "lo que denomina 'invalidación' se refiere genéricamente a los 'actos contrarios a derecho', sin determinar distintos grados de invalidez, a efectos de su revisión. En algún precepto aislado se habla de 'nulidad' -así, en el artículo 47-, pero sin rigor técnico como grado de invalidez distinto de la anulabilidad. Y, por supuesto, no se contempla el supuesto del llamado irregular, es decir, el acto que, aun contraviniendo el ordenamiento jurídico, es válido". Jesús González Pérez, "La ley chilena de derecho administrativo", Revista de Administración Pública, n. ${ }^{\circ}$ 162, 2003, p. 381.

35 "La crítica que se formula al legislador respecto a las ilegalidades -sanables e insanables-es que entrega a la jurisprudencia la determinación de qué vicios serán de una u otra entidad lo que debilita el principio de legalidad pues corresponde al la ley regular dicha cuestión". Carlos Garrido Dorn, "Ley de Bases de Procedimiento Administrativo...", óp. cit., p. 15.

36 La Corte Suprema ha formulado este criterio de la siguiente manera: "En efecto, todo contrato administrativo se rige por sus estipulaciones, por las normas legales y reglamentarias que lo regulan, por las bases de licitación, por la oferta adjudicada y por las demás prescripciones técnicas" (considerando décimo), sentencia de 27 de diciembre, recaída en causa Rol n. ${ }^{\circ}$ 45578-2017. En el mismo sentido, ver las sentencias recaídas en causas roles n. ${ }^{\circ}$ 16.629-2016 (considerando duodécimo), n. ${ }^{\circ}$ 24.212-2019 (considerando séptimo) y n. ${ }^{\circ} 12.367-2020$ (considerando noveno). 
Por consiguiente, para obtener elementos que coadyuven a un mejor funcionamiento del instituto de nulidad en sede contractual es necesario realizar una revisión sobre la operatoria de dicho instituto. Para ello, se analizarán dos momentos importantes de la contratación pública a fin de analizar la jurisprudencia e identificar tendencias o líneas jurisprudenciales y determinar las circunstancias asociadas y las causas por las que surge la problemática de la nulidad contractual en el ámbito administrativo.

\subsection{LA NULIDAD EN LA ETAPA PRECONTRACTUAL: LA IMPORTANCIA DEL ITER DE LA CONTRATACIÓN}

De acuerdo con el artículo 9. ${ }^{\circ}$ de la LOCBGAE, la contratación administrativa ha de realizarse preferentemente previa propuesta pública, la que se guiará por dos principios fundamentales: a) la libre concurrencia de los oferentes; y b) la igualdad ante las bases que rigen el contrato. Estos son los principios básicos que se deberán observar en el iter contractual regular. En tal sentido, centraremos el análisis en la licitación pública, descartando la licitación privada y el trato directo como modalidades de contratación a examinar en este estudio.

En esta etapa son tres los órganos relevantes en el control del cumplimiento del procedimiento para celebrar un contrato público: la Contraloría General de la República, cuya competencia es universal en tanto entidad fiscalizadora de toda la Administración del Estado; el Tribunal de la Contratación Pública, particularmente, para los contratos de suministros y de servicios que se celebren a través de la Ley n. ${ }^{\circ} 19.886$; y los tribunales de justicia, los que constituyen el último y más intenso control de las decisiones administrativas.

La anulación en la etapa precontractual se refiere a actos administrativos que contienen decisiones no conformes a derecho adoptadas durante el procedimiento de adjudicación que se inicia con el llamado a la propuesta pública y finaliza con la aprobación del contrato mediante una resolución tomada razón (en los casos que corresponde cumplir este trámite). En consecuencia, las leyes n. ${ }^{\circ} 19.880$ y n. ${ }^{\circ} 19.886$ son los cuerpos normativos más empleados para dilucidar las controversias sobre invalidación de actos trámite en la etapa precontractual que se desarrollan al hilo del procedimiento concursal. El artículo 7 de la CPR solo constituye un marco general del reproche a la infracción al deber de juridicidad, pero no tiene una aplicación universal en el sentido de imponer generalizadamente una sanción directa de nulidad de pleno derecho, ni tampoco que ella opere prescindiendo de una declaración a tal efecto.

De los tres órganos que participan en el control en esta etapa se puede señalar que ha sido la Contraloría General la que mediante la jurisprudencia administrativa ha mantenido su tradicional preponderancia. En parte porque en sus manos se encuentra precisamente el trámite de toma de razón que supone un control de la juridicidad del contrato público, necesario para la validez y 
eficacia del acto que aprueba el contrato ${ }^{37} \mathrm{y}$, por otro lado, porque los fallos del Tribunal de la Contratación Pública (para los contratos de suministros) no consiguen ser oportunos para la corrección del procedimiento licitatorio, lo que desincentiva reclamar ante dicho órgano.

Ahora bien, la toma de razón en materia de contratación pública está asociada al volumen del gasto que esta involucra, por lo que en casos relevantes (por ejemplo, compras de FONASA, CENABAST, FF. AA. y FFOO, contratos de obra pública, etc.) el órgano contralor -en caso de advertir una situación irregularpuede realizar el trámite de toma de razón acompañado de un pronunciamiento, emitiendo un dictamen que resulta de obligatorio cumplimiento para el correspondiente servicio público, el que puede verse así obligado a rectificar a fin de poder superar los reparos que impiden la toma de razón. De otro lado, la Contraloría también puede recibir reclamos o denuncias de los interesados en una licitación, a raíz de lo cual puede solicitar informes al servicio o incluso dar inicio a un procedimiento de fiscalización.

De este modo, los dictámenes pueden suponer la invalidación de algún acto trámite, retrotraer el procedimiento a una etapa anterior, invalidar el acto de adjudicación de la licitación o incluso iniciar un nuevo procedimiento licitatorio, además de ordenar perseguir las responsabilidades administrativas, en casos graves.

En esta etapa, la anulación puede afectar a cláusulas o condiciones de los pliegos o bases licitatorias administrativas, técnicas o económicas ilegales o arbitrarias, especialmente aquellas que resultan discriminatorias. Son también susceptibles de ser afectadas con la nulidad, las condiciones reguladoras del contrato o cualquier otra documentación relacionada con la licitación o adjudicación.

El resguardo de los principios de sujeción estricta a las bases licitatorias ${ }^{38}$ y de libre concurrencia de los oferentes ${ }^{39}$ es el que propicia la invalidación en

La jurisprudencia de la Contraloría General sujeta el derecho del adjudicatario a suscribir el contrato a que el acto de adjudicación se haya dictado conforme a derecho, así el Dictamen n. ${ }^{\circ} 22.265 / 2020$, reitera: "En ese sentido, cabe señalar que la convocatoria pública constituye un procedimiento reglado que se afina con la adjudicación, por lo tanto, una vez que esta se encuentra válidamente notificada nace, para las partes, el derecho a suscribir el respectivo convenio de transferencia, por cierto, en la medida que ese acto haya sido dictado conforme a derecho (aplica criterio contenido en los dictámenes n. ${ }^{\circ} 34.053 \mathrm{de}$ 2013 y n. ${ }^{\circ} 33.010$ de 2015 , ambos de este origen)".

38 El Dictamen n. ${ }^{\circ} 23.313 / 2018$ se pronuncia en el sentido: "la jurisprudencia administrativa de este organismo de fiscalización ha precisado que las bases o condiciones generales de los procedimientos licitatorios integran el marco jurídico aplicable a los derechos y obligaciones tanto de la Administración como de los oponentes al correspondiente certamen, y que a él deben ceñirse necesariamente quienes participan en un proceso de esa naturaleza, a fin de respetar la legalidad y transparencia que tienen que primar en todos los contratos que celebre aquella". En el mismo sentido, véase dictámenes n. ${ }^{\circ}$ 9.478/2016 y n. ${ }^{\circ}$ 25.330/2013

39 El Dictamen n. ${ }^{\circ} 25.330 / 2013$ afirma: "la jurisprudencia administrativa, contenida en los dictámenes n. ${ }^{\circ} 27.268 / 2010,{ }^{\circ}{ }^{\circ} 70.019$ y 75.915 , ambos de 2011 , entre otros, ha 
la etapa precontractual de la contratación. La jurisprudencia administrativa es abundante en este sentido, al igual que los fallos del Tribunal de la Contratación Pública (TCP), y en ambos casos estos órganos, apoyados tanto en el principio de no formalización de los procedimientos administrativos (artículo 13 de la LBPA), como en la relevancia que ha cobrado el resguardo de la competencia en el mercado público, han ido transitando de forma aún vacilante desde una interpretación formalista-del principio de sujeción a las bases- hacia una prevalencia del principio de libre concurrencia ${ }^{40}$. Ello encuentra justificación en el interés general que conlleva el favorecimiento de la eficacia, eficiencia y economía de las compras públicas que redunda en la obtención del "mayor valor por dinero" que se asocia a un buen uso de los recursos públicos involucrados en la contratación pública.

El TCP ha advertido que los dos principios básicos de la contratación pública mencionados pueden, en ciertas circunstancias, contraponerse y deja en manos de la autoridad decidir razonablemente cuál debe prevalecer, superando una interpretación meramente formal del proceso concursal ${ }^{41}$.

manifestado que el principio de libre concurrencia de los participantes establecido en el inciso segundo del artículo $9 .^{\circ}$ de la Ley n. ${ }^{\circ} 18.575$, persigue considerar las ofertas de todos los proponentes que han cumplido con los pliegos de condiciones, sin que por errores sin trascendencia y no esenciales queden fuera de concurso".

40 En un amplio estudio casuístico sobre el TCP se pudo observar que para determinar si acoge o rechaza la demanda de impugnación, el análisis que realiza el TCP del principio de estricta sujeción a las bases "consiste en un estudio eminentemente formal, consistente en una mera comparación entre el pliego y los hechos, ya sea porque se aceptaron propuestas de oferentes que no presentaron la documentación requerida, porque se adjudicó a quien no se encontraba dentro de las bases o cuya oferta no era la mejor evaluada, en condiciones de que las bases exigían mayores requisitos para adjudicarlo a un oferente distinto del primer puntaje, entre otros". Natalia Acevedo Alvear, Licitación pública: regulación y concurrencia, memoria para optar el grado de Licenciada en Ciencias Jurídicas y Sociales, Santiago, Universidad de Chile, 2015, p.82. Sin embargo, hay sentencias del TCP que permiten avizorar el paulatino cambio de criterio, así "se ha vulnerado el principio de igualdad de los oferentes [...]. En este sentido, a juicio de este tribunal existió una efectiva vulneración a este principio, toda vez que por una razón formal absolutamente susceptible de ser subsanada a requerimiento de la autoridad licitante o bien omitida para su correcta evaluación ya que no provocaba perjuicio alguno [...] dejando al demandante sin la posibilidad de participar en la evaluación, todo ello, reiteramos, por una razón meramente formal"(considerando $15 .^{\circ}$ ). Sentencia de 30 de diciembre de 2010, recaída en causa Rol n. ${ }^{\circ} 21-2010$

41 "El principio de no formalización es, a su vez, un límite al principio de estricta sujeción a las bases, pues implica que debe privilegiarse la libre concurrencia, pese a que ciertos oferentes hayan transgredido las bases, en aspectos que no resulten esenciales. Sin embargo, esto cambia en los casos en que las bases establecen requisitos específicos en forma imperativa. Así, se resolvió por el TCP en Rol 270-2010 (Ficha 56), fallo del cual se concluye que el principio de estricta sujeción a las bases prima sobre el principio de no formalización, cuando el pliego de condiciones ha establecido qué aspectos resultarán esenciales, aunque ello no se señale expresamente". Ibíd. p. 90. 
Con todo, la Ley n. ${ }^{\circ} 19.886$ configura al TCP como un órgano jurisdiccional de tutela anulatoria, por lo que al reclamar ante él lo que se busca es la invalidación de algún acto licitatorio por infracción a la legalidad que debe guiar el proceso $y$, en consecuencia, obtener el efecto de retrotraer el procedimiento al estado anterior al acto reprochado. Sin embargo, los estudios realizados en torno a cómo resuelve el $\mathrm{TCP}^{42}$ indican que la declaración de ilegalidad que realiza dicho tribunal no necesariamente genera efectos anulatorios, pues en la interpretación que realiza de cómo debe ejercer sus facultades le permite reconocerse una amplia discrecionalidad para determinar las medidas tendientes a restablecer el imperio del derecho cuando acoge el respectivo reclamo ${ }^{43}$, procurando armonizar el respeto a la legalidad con la protección del interés público que conlleva ínsita la contratación pública.

Son varias las justificaciones que a este respecto el TCP plasma en su jurisprudencia, las principales están referidas a principios como la buena fe, la seguridad jurídica y los conceptos jurídicos indeterminados, como interés público, derechos adquiridos y situaciones jurídicas consolidadas. Todos ellos requieren una concretización en el caso particular. De ahí que resulte necesario, al menos, abordar brevemente algunas de estas nociones limitantes al efecto anulatorio de un acto licitatorio por parte del Tribunal de la Contratación.

a. El principio de buena fe: La naturalización de la aplicación supletoria del derecho privado que admite la Ley $n{ }^{\circ} 19.886$ permite que el TCP emplee la buena fe como una limitante a los efectos retroactivos de la declaración de ilegalidad del acto licitatorio recurrido. Mediante la aplicación de este principio, el TCP busca proteger la actuación correcta y leal que ha guardado el adjudicatario de una licitación y que no ha intervenido en los vicios de ilegalidad que el oferente reclamante reprocha de la entidad licitante ante el TCP. Es común que a este respecto suela justificar la no anulación del acto de adjudicación con la siguiente consideración "De[be] destacarse que el adjudicatario resulta ser un tercero, que no ha sido parte en este juicio y que no ha intervenido en el acto impugnado, ni contribuido a causar la ilegalidad y arbitrariedad declarada, ni tampoco consta que haya existido mala fe en su actuación en el proceso" ${ }^{\prime 4}$.

42 Rodrigo Muñoz Cárdenas, La nulidad y sus efectos. Causales del Tribunal de Contratación Pública para negar la retroactividad, memoria para obtener el Grado de Licenciado en Ciencias Jurídicas y Sociales, Santiago, Universidad de Chile, 2017, pp. 32-82.

43 El TCP suele reiterar en sus sentencias: "Cabe señalar en este sentido que el citado artículo no establece que la declaración judicial de ilegalidad y/o arbitrariedad de una acción u omisión produzca por sí misma un efecto anulatorio, toda vez que lo que dispone, es que el tribunal en su caso, ordenará las medidas necesarias para reestablecer el imperio del derecho" (considerando $18{ }^{\circ}$ ). Sentencia 30 de diciembre de 2010, recaída en causa Rol n. ${ }^{\circ}$ 21-2010.

44 Sentencia del TCP de 10 de septiembre de 2010, recaída en causa Rol n. ${ }^{\circ}$ 84-2009 (considerando $23 .^{\circ}$ ). En el mismo sentido, sentencias en las causas Roles n. ${ }^{\circ}$ 120-2009 (considerando $16 .^{\circ}$ ), n. ${ }^{\circ} 30-2010$ (considerando $18 .^{\circ}$ ), n. ${ }^{\circ}$ 200-2011 (considerando $35 .^{\circ}$ ), n. ${ }^{\circ}$ 132-2012 (considerando $17 .^{\circ}$ ). 
Bajo la invocación del principio de buena fe. el TCP protege la confianza que genera el acto de adjudicación respecto del adjudicatario, quien al presumir estar amparado por el derecho ha orientado su actuación hacia el cumplimiento del respectivo contrato (incurriendo en costos y enderezando sus esfuerzos hacia ese objetivo). Además, con ello, el TCP cumple con no perjudicar el interés general que reconoce en el contrato que la entidad licitante ha logrado perfeccionar a fin de cumplir sus funciones institucionales, aunque esta haya incurrido en error o generado vicios en el procedimiento licitatorio que pudieran afectar la legalidad de procedimiento concursal y el contrato que de él se deriva ${ }^{45}$.

b. Los derechos adquiridos: La afectación de los derechos adquiridos es una de las justificaciones más recurrentes que tiene el TCP para no invalidar un acto reprochado por ilegalidad por alguno de los oferentes de un procedimiento licitatorio. En este apartado se reflexionará especialmente en el acto de adjudicación de un contrato de suministros o de servicios regulado por la Ley n. ${ }^{\circ}$ 19.886. El DS 250 de 2004 del Ministerio de Hacienda contiene dos disposiciones importantes en relación con el surgimiento del contrato: a) la obligación de formalizarlo (artículo 63); y b) la obligación de suscribirlo por el órgano licitante y el adjudicatario dentro del plazo fijado en las bases (artículo 65). A partir de ambos textos normativos, el TCP reconoce un derecho adquirido del adjudicatario a que se celebre en fecha determinada el contrato respectivo, reforzando la protección de su posición jurídica en desmedro de los oferentes reclamantes. Ello supone diferenciar el derecho a que se celebre el contrato de los derechos que surgen del contrato. Además, nos enfrenta a la problemática de los derechos de propiedad sobre cosas incorporales, surgido del acto administrativo de adjudicación (sobre el cual la Administración aún puede ejercer su potestad invalidatoria, de acuerdo con el artículo 53 de la LBPA) y no del contrato.

El derecho a la celebración del contrato se erige como un derecho adquirido que se encuentra en el límite de la competencia del TCP y resulta determinante en su jurisprudencia que, expresamente, le otorga el amparo del derecho de propiedad reconocido por el artículo 19 n. ${ }^{\circ} 24$ de la $\mathrm{CPR}^{46}$. Además, limita el ejercicio de su facultad invalidante $y$, por tanto, la posibilidad de retrotraer dicatario amparados en su ejercicio por una garantía constitucional expresa, como lo es la establecida en el articulo 19 número 24 de la Constitución Política del Estado, quien resulta ser un tercero que no ha sido parte en esta causa respecto de quien además, no se ha demostrado que de algún modo haya intervenido en el acto ni contribuido a causar ilegalidad declarada, ni que haya existido mala fe en su obrar en el proceso que dio origen a la propuesta publica" (considerando décimo noveno). Sentencia TCP, de 8 de junio de 2012, recaída en causa Rol n. ${ }^{\circ}$ 114-2011. En el mismo sentido ver sentencias recaídas en las causas Rol n. ${ }^{\circ} 251-2011$, n. $^{\circ} 232-2012$ y n. ${ }^{\circ} 135-2015$, 
el procedimiento licitatorio a una etapa previa ${ }^{47}$. Lo señalado ha propiciado que la declaración de ilegalidad del acto de adjudicación por parte del TCP no conlleve necesariamente su nulidad.

Sin embargo, el TCP no logra argumentar consistentemente desde los principios y reglas del derecho público como corresponde. Si bien el procedimiento licitatorio termina con la adjudicación, acto mediante el cual la autoridad selecciona a uno o más oferentes para la suscripción del contrato $\left(n{ }^{\circ} 1 \mathrm{del}\right.$ artículo 2, DS 250 de 2004, de Ministerio de Hacienda), ello, en el campo del derecho público, no puede ser equiparado al surgimiento del respectivo contrato que es, en definitiva, el generador de los derechos del adjudicatario por una razón básica: la Administración carece de autonomía de voluntad (presupuesto elemental de la contratación en el derecho privado), muy por el contrario, es un poder público reglado. Esta realidad es la que impide aceptar que con la adjudicación se haya producido el consentimiento necesario para el surgimiento del contrato y que dicho acto es el que tiene el efecto de producir la coincidencia de voluntades entre las partes. Más aún, la Administración es un poder público que no solo tiene la facultad, sino que está obligado a ejercer un autocontrol invalidando sus actos administrativos contrarios a derecho $\mathrm{o}^{48} \mathrm{y}$ ciertamente, al ser un poder controlado, se encuentra obligado a cumplir una serie de trámites para la eficacia de sus decisiones, entre ellos, el más importante es el de toma de razón cuando su decisión está afecta.

El acto de adjudicación, ciertamente, hace surgir una posición jurídica protegida por parte del adjudicatario, pues este es el oferente al cual le ha sido aceptada una oferta o cotización (n. ${ }^{\circ} 2$ del artículo 2, DS 250 de 2004 , de Ministerio de Hacienda). Por lo tanto, este tiene una legítima expectativa para que el contrato se celebre, pero hasta entonces no se puede afirmar que el contrato se perfeccionó. El contrato de suministro requiere de formalización, la cual solo se produce con su suscripción o mediante la emisión de la orden de compra y su aceptación por el proveedor para adquisiciones menores de 100 uTM (artículo 63, DS 250 de 2004, de Ministerio de Hacienda), solo así se puede afirmar la existencia del contrato, aunque no su total eficacia, si es que la resolución que lo aprueba requiera cumplir el trámite de toma de razón, lo que no obsta a que el servicio tenga responsabilidad por los perjuicios causados.

En suma, se advierte que la reiterada jurisprudencia del TCP para desestimar imponer la nulidad de los actos de adjudicación, fundándose en la protección constitucional de los derechos adquiridos, no es del todo correcta. derechos adquiridos legítimamente por el adjudicatario del contrato" (considerando décimo séptimo). Sentencia de 29 de agosto de 2014 , recaída en causa Rol n. ${ }^{\circ}$ 132-2012. Como fundamentos normativos de este aserto se pueden mencionar los incisos 1 y 2 del artículo 6, 99 de la CPR; y los artículos 2 y 11 de la LOCBGAE. También ver dictamen n. ${ }^{\circ}$ $24.337 / 2002$. 
c. El interés general: Hay un matiz importante que el TCP no advierte con suficiente claridad y que lo lleva a limitar sus decisiones anulatorias. Según el razonamiento que expresa el TCP, la presencia de la Administración pública siempre está asociada con el interés público, resultando esta la poseedora del interés general y, por tanto, lo propio es que este interés representado por la Administración prevalezca ${ }^{49}$. Siguiendo este razonamiento se pronuncia:

para resolver esta materia debe tenerse en cuenta que la institución demandada, al convocar la licitación que tuvo como fin satisfacer una necesidad pública, cual es la obtención de un medicamento destinado a preservar la salud de eventuales pacientes. En este caso, la supremacía del interés general ha surgido como una limitación necesaria a la facultad jurisdiccional de este Tribunal para constreñir los efectos propios de la anulación de un acto administrativo, omitiendo deliberadamente una declaración de retroactividad, que, además de ser inoportuna provocaría perjuicio al interés público, inseguridad jurídica y perturbación de derechos de terceros, calidad que posee el adjudicatario ${ }^{50}$.

Mas como señala el maestro Meilán, la Administración no es titular del interés general, más bien sirve al interés general ${ }^{51}$, y por tanto no es la titular del mismo, ni siempre debe prevalecer, y muy por el contrario, ello exige un intenso control a fin que la actuación de la Administración se realice desde una posición de servicialidad con fidelidad a ese interés general.

Con todo, es posible colegir que a pesar de que el TCP intenta justificar sus fallos en los principios y conceptos que se han comentado, sus decisiones no invalidatorias - en los casos en los que correspondería fallar en ese sentido y ordenar retrotraer el procedimiento licitatorio- se deben más a la falta de oportunidad que tienen sus sentencias. Es de público conocimiento que las causas que ahí se tramitan pueden durar de uno a tres años, o incluso más,

49 " $[\ldots]$ resulta evidente que para conseguir tal finalidad deben atenderse, entre otros elementos, al contenido del acto u omisión impugnado y al grado de desarrollo de sus efectos, a la naturaleza y magnitud de la eventual lesión causada al interés privado de quien ha accionado por esta vía, a la conveniencia y posibilidad fáctica de retrotraer el estado de las cosas al que se encontraba antes de ejecutarse la acción o incurrir en la omisión materia del reproche y también a los propios efectos de la sentencia que declara su ilegalidad o arbitrariedad, cuidando que éstos no perjudiquen el interés público comprometido en la mayor parte de los actos administrativos que en materia de licitaciones deben realizar los órganos de la administración para satisfacer necesidades del mismo carácter" (considerando 22). Sentencia de 11 de octubre de 2012, recaída en causa Rol n. ${ }^{\circ}$ 251-2011.

50 Sentencia de 27 de agosto de 2015, recaída en causa Rol n. ${ }^{\circ} 222-2012$.

51 "En definitiva ni el titular del poder -Gobierno o Administración- deben apropiarse del interés general o el interés público, como si fueran domini de ellos, ni pueden desentenderse a favor del interés privado, abdicando ilegítimamente de su función". José LuIS MEILÁN GIL, "Intereses generales e interés público desde la perspectiva del derecho público español", $A_{\&} C$ Revista de Direito Administrativo \& Constitucional, n. ${ }^{\circ} 40,2010$, p. 174. 
plazos que a todas luces es excesivo para todas las partes interesadas en una licitación pública. Esta circunstancia se constata a través de la simple comparación entre el año del rol de la causa y la fecha de la respectiva sentencia, dato que es indicativo de la duración del juicio. El TCP es un tribunal administrativo débilmente configurado, lo que compromete seriamente su eficacia ${ }^{52}$.

Como paliativo de esta situación, cuando el tribunal tiene la convicción que la infracción a la legalidad es de cierta entidad, suele aparejar en su fallo el reconocimiento del derecho a reclamar la justicia restitutoria en los tribunales ordinarios, declaración que no tiene ningún efecto jurídico importante ni es necesaria para que el oferente que quiera reclamar indemnización inicie un juicio de lato conocimiento de responsabilidad por los perjuicios causados. Así, en reiterada jurisprudencia suele pronunciarse de este modo:

lo anterior no significa eximir de responsabilidad a los órganos de la Administración del Estado y a los agentes que han obrado en su representación ejecutando los actos administrativos que han merecido la calificación de arbitrarios e ilegales, puesto que, $[\ldots]$ aquellos interesados que, con ocasión del agravio han sufrido perjuicios, podrán entablar, ante el Tribunal que sea competente, las acciones indemnizatorias que crean corresponderles (considerando 24$)^{53}$.

En la fase de preparación y adjudicación de los contratos, la "voluntad" de la Administración se perfecciona de un modo complejo. El punto álgido en esta fase está en relación con el acto de adjudicación, pues se formula a través de una resolución exenta del trámite de toma de razón. Por ello, la jurisprudencia ha admitido la facultad que tiene el servicio respectivo para o bien revocarlo, si carece de falta de objeto y oportunidad (vr. gr., si el adjudicatario rechaza la orden de compra), facultad solo limitada por la consumación de los efectos del acto o por la existencia de derechos adquiridos ${ }^{54}$; o bien de invalidarlo, otorgando audiencia previa al afectado, si resulta contrario a derecho y en su caso, retrotraer el procedimiento licitatorio ${ }^{55}$, aunque en caso de existir responsabilidad patrimonial por los daños causados, la Contraloría General ha señalado que esta deberá discutirse en sede jurisdiccional por ser materia de naturaleza litigiosa ${ }^{56}$.

52 Véase Gladys Camacho Cépeda, "El Tribunal de la Contratación Pública en Chile: una década de funcionamiento", en Eloy Espinosa Saldaña (dir.), Tendencias actuales en contratación pública, Lima: Gaceta Jurídica, 2014, pp. 165-176. Sentencia de 27 de agosto de 2015, recaída en causa Rol n. ${ }^{\circ} 222-2012$. Dictámenes n. ${ }^{\circ} 5448$ de 2015, n. ${ }^{\circ} 7.041$ de 2013 y n. ${ }^{\circ} 2.641$ de 2005. dicó la licitación pública. Dictamen n. ${ }^{\circ} 23.315$ de 2018. En el mismo sentido, el Dictamen n. ${ }^{\circ} 28.477$ de 2006. 
Por su parte, una vez suscrito por ambas partes el contrato, este instrumento deberá complementariamente aprobarse por una resolución que, en los casos de contratos que involucren montos de cierta significación, deberá cumplir el trámite de toma de razón ${ }^{57}$. El no superar este trámite (por reparo del órgano contralor), impide que la "voluntad" contractual de la Administración sea eficaz ad extra ${ }^{58}$, por consiguiente, será la decisión unilateral de la Administración la determinante para que surja la relación jurídico-pública de carácter bilateral ${ }^{59}$. Ello es así, por cuanto la Administración no es un sujeto que goza de autonomía de voluntad sino uno que está reglado por el derecho, sometido a las formalidades y tramitaciones que éste le demanda.

\subsection{LA ETAPA DE EJECUCIÓN DEL CONTRATO Y SUS MODIFICACIONES}

En esta etapa son dos los órganos de control de la contratación pública que intervienen: la Contraloría General y los tribunales ordinarios de justicia. Las pretensiones de invalidación en materia contractual, en esta etapa, están en relación con actos que afectan el equilibrio económico del contrato y las modificaciones del contrato. Se parte de la "ley del contrato" como eje para resolver las controversias, y dado el vacío normativo que se padece en esta materia, tanto la jurisprudencia administrativa como judicial, se remiten al Código Civil para resolver los conflictos que se suscitan en relación con la interpretación de los contratos, condición resolutoria tácita, equilibrio económico y modificación del contrato, entre otros.

57 La Contraloría General ha fijado normas sobre exención del trámite de toma de razón mediante las resoluciones $\mathrm{n} .{ }^{\circ} 6, \mathrm{n} .{ }^{\circ} 7 \mathrm{y} \mathrm{n} .{ }^{\circ} 8$, todas de 2019.

58 "Dado que la propia Administración que dictó la resolución no puede desconocer su vigencia, la sola dictación del acto administrativo conlleva obligaciones ad intra para la Administración que lo dictó para promover su eficacia ad extra, esto es respecto de los destinatarios de la decisión adoptada. En este sentido, la primera obligación es cumplir con los trámites a los que está afecto o el decreto o resolución administrativa (por ejemplo, visación, registro, toma de razón) y enseguida, su publicidad". GLADYS CAMACHO CéPEDA, "La eficacia del acto administrativo", Revista de la Facultad de Derecho de México, t. LXIX, n.o 274, 2019, p. 76.

59 Desde muy temprano la jurisprudencia administrativa ha relevado la importancia del cumplimiento del trámite de toma de razón para la eficacia jurídica y obligatoriedad de los actos administrativos "un decreto supremo legalmente tramitado tiene pleno valor y eficacia jurídica dentro de la Administración pública y debe por tanto ser cumplido y respetado por funcionarios públicos no siéndoles lícito excusarse de cumplirlo a pretexto de supuesta ilegalidad del mismo, ya que una vez que ha sido tramitado y tomado razón por contraloría se ha establecido una verdadera presunción de legalidad", Dictamen n. ${ }^{\circ}$ 1.589 de 1957. En el mismo sentido, dictámenes n. ${ }^{\circ} 23.190$ de $1961, n{ }^{\circ} 11.191$ de $1976 \mathrm{y}$, más recientemente, $n{ }^{\circ}{ }^{\circ} 35.058$ de 2013 . Además, la propia ley orgánica de la Contraloría General, le ordena que ésta deberá velar porque los decretos o resoluciones no se comuniquen antes que de ellos haya tomado razón el Contralor (artículo 154 de la LOCCGR). 
Si bien la jurisprudencia de la Corte Suprema distingue la institución del contrato público del instituto acto administrativo ${ }^{60}$, termina habilitando la acción de nulidad correspondiente (ordinaria o especial) a partir de la acción u omisión en que haya incurrido el órgano o magistratura de la Administración que conlleve una grave infracción al principio de legalidad ${ }^{61}$. Junto con ello, ha desarrollado algunos criterios jurisprudenciales entre los que destacan los siguientes: a) corresponde que la autoridad ejerza su facultad revocatoria y no anulatoria respecto de una resolución que aprueba la modificación de contrato representada por la Contraloría General ${ }^{62}{ }_{i}$ b) cuando el contrato contemple

60 En relación a un contrato de compraventa de inmueble municipal realizado sin contar con la preceptiva autorización del concejo municipal, la Corte Suprema sostiene: "no se trata de un acto administrativo de aquellos definidos en el artículo 3 de la Ley n ${ }^{\circ}{ }^{19.880,}$ desde que no estamos en presencia de una decisión o declaración unilateral de voluntad de un órgano de la Administración del Estado [...], desde luego porque no se trata de una resolución u omisión de la Municipalidad demandada, sino de un contrato bilateral o convención en el que ha intervenido como tradente la máxima autoridad municipal". Sentencia de 28 de julio de 2020, recaída en causa Rol n. ${ }^{\circ}$ 29.317-2019 (considerando undécimo).

61 "[al] actuar el señor Alcalde en representación de la Municipalidad demandada, [...] habilita para colegir que se está en presencia de una hipótesis nulidad de derecho público, en vista del cual, de acuerdo a lo que se ha venido desarrollando, se puede utilizar el procedimiento de juicio ordinario para instar a la declaración de nulidad del acto" (considerando undécimo) y continúa "si bien el contrato de compraventa objeto del juicio no es un acto administrativo, al haber intervenido en su celebración una autoridad de la Administración cuya actuación está regida por el principio de legalidad [... el mismo adolece de un vicio que debe ser sancionado con su ineficacia" (considerando undécimo). Sentencia de 28 de julio de 2020, recaída en causa Rol n. ${ }^{\circ}$ 29.317-2019.

62 La Corte Suprema en la sentencia de 29 de octubre de 2018, recaída en causa Rol n. ${ }^{\circ}$ 44.629-2017, comparte los fundamentos de los tribunales de primer y segundo grado en el sentido que la resolución que aprueba la modificación de un contrato de obra pública que por el monto involucrado debía pasar el trámite de toma de razón, luego de ser reparada por la Contraloría General y no superar dicho trámite, puede ser revocada por el servicio respectivo mediante una resolución exenta que al eliminar el gasto deja de estar afecta. De acuerdo al criterio del sentenciador de primer grado con el que concuerda la Corte, no puede ser estimada "la falta del trámite de toma de razón como motivo de ilegalidad fundante del acto revocatorio" de la resolución por cuanto el acuerdo de modificación de contrato de ejecución de obra, celebrado mediante escritura pública, estaba sometido a una condición suspensiva que resultó fallida. La resolución que aprobaba dicha modificación puede ser revocada por la autoridad aplicando el artículo 61 de la LBPA, pues "no corresponde el ejercicio de facultad de anulación contemplada en el artículo 53 de la mencionada ley" ya que "al ejercer la facultad de revocación el Servicio [...] se ajustó a los requisitos contemplados en el artículo 61 de la Ley n. ${ }^{\circ} 19.880$, toda vez que no invocó un motivo de ilegalidad como fundamento para hacer cesar en sus efectos a la Resolución [...], por lo que no ha incurrido en desviado ejercicio de su facultad de anulación, toda vez que no resultaba aplicable, en la especie, el artículo 53 de la misma ley". En este caso, tampoco puede prosperar la acción de nulidad de derecho público respecto del acto administrativo revocatorio por cuanto lo que se revocaba no era un acuerdo entre las partes sino una decisión administrativa, pues: "No cabe entender que la resolución administrativa que apruebe 
la vía para discutir un incumplimiento contractual corresponde emplear la acción especial de reclamo de ilegalidad ${ }^{63}{ }_{i}$ c) es acertado declarar la nulidad de derecho público de un acto que terminó unilateralmente un contrato cuyo plazo de vigencia estaba cumplido, por lo que dicho acto carece de motivación ${ }^{64}{ }_{i}$ y d) si la ley no contiene procedimiento o acción especial para reprobar el acto administrativo se puede utilizar el procedimiento ordinario, pero habiendo empleado uno de los múltiples procedimientos especiales de reclamación de ilegalidad de los actos administrativos, resulta inconcuso que la acción de nulidad de derecho público ya ha sido ejercida. No toda ilegalidad de un acto administrativo lleva aparejada su nulidad, por cuanto uno de los dogmas que informan la nulidad de derecho público es el de conservación ${ }^{65}$.

una modificación contractual, en la cual la administración haya obrado como parte, por ese solo hecho, mute su naturaleza jurídica de acto administrativo a convención, y con ello, para su extinción, sean aplicables las normas relativas a la extinción de los contratos o convenciones, toda vez que la naturaleza jurídica de acto administrativo de la resolución emanada de un servicio público no puede ser alterada en virtud de la naturaleza del hecho o acto que sea objeto de su regulación"(considerando undécimo).

63 En la sentencia de 20 de agosto de 2020, recaída en causa Rol n. ${ }^{\circ}$ 27.488-2020, la Corte Suprema resolvió que "el contrato contenía un procedimiento especial de reclamo por la eventual imposición de multas por incumplimiento contractual, el cual no podía ser soslayado por la reclamante y que, cualquier incumplimiento contractual, debía ser discutido en la instancia pertinente, declarativa de derechos, dejando a salvo las acciones de la reclamante" (considerando décimo).

64 En la sentencia de reemplazo de 30 de abril de 2020, recaída en causa Rol n. ${ }^{\circ} 31.810$ 2018, la Corte advierte: "a la fecha en que se expidió y fue notificado [...] ya no existía contrato alguno al que poner término" (considerando $8 .^{\circ}$ ) "los sentenciadores han decidido acertadamente, al declarar la nulidad de derecho público del citado acto, toda vez que, como resulta evidente, este carece de la motivación exigida a su respecto por los artículos 11 y 41 de la Ley n. ${ }^{\circ} 19.880^{\prime \prime}$ (considerando 9..$^{\circ}$ ).

65 En la sentencia de 2 de julio de 2019, recaída en causa Rol n. ${ }^{\circ}$ 29.094-2018, la Corte Suprema concluye que los artículos 6 y 7 de la CPR "no consagran una determinada acción procesal en caminada a conseguir la anulación de los actos administrativos" sino la posibilidad de recurrir ante los tribunales de justicia para lograr la anulación de los actos contrarios a derecho. Reconoce bajo el rótulo de "acción de nulidad de derecho público" acuñada por la doctrina y jurisprudencia a "toda acción contenciosa administrativa dedicada a obtener por parte de un tribunal de la República la anulación de un acto administrativo" (considerando décimo noveno), acciones especiales que pueden encontrarse determinadas por el legislador para situaciones concretas y materias específicas y solo en el evento que "la ley no con[tenga] ningún procedimiento o acción especial para reprobar el acto administrativo solicitando su anulación, se puede utilizar el procedimiento de juicio ordinario" (considerando vigésimo), "habida cuenta que uno de los múltiples procedimientos especiales de reclamación de la ilegalidad de los actos administrativos fue, precisamente, el utilizado por la demandante para impugnar la Resolución n. ${ }^{\circ} 1.324$ de 2011 [...] por la cual se rechazaron los recursos intentados en contra de la Resolución n. ${ }^{\circ} 773$, materia de este juicio, resulta inconcuso que la acción de nulidad de derecho público ya ha sido ejercida por la actora y que esta ha sido resuelta en definitiva" (considerando vigésimo primero). 


\section{CONCLUSIONES}

En el derecho chileno se ha construido un instituto denominado "nulidad de derecho público" a partir del artículo 7 de la CPR, pero al carecer dicha prescripción constitucional de desarrollo legislativo, no hay consenso doctrinal ni jurisprudencial sobre sus efectos ni sobre los recursos y acciones que pueden ejercitarse a fin de restablecer el derecho y las responsabilidades que hubiere a lugar. De acuerdo con la jurisprudencia analizada la nulidad de derecho público no opera indefectiblemente de pleno derecho y con prescindencia de su declaración. Lo que sí, los requisitos exigidos para una actuación válida por el artículo 7 de la CPR constituyen las causales que pueden dar lugar a producir la nulidad del acto unilateral o bilateral que se produce en torno a la actividad contractual de la Administración.

El artículo 7 de la CPR, al ser una norma constitucional que forma parte de nuestras bases institucionales, también irradia sobre la particular problemática de la nulidad en materia contractual, tanto en la fase precontractual como en la de ejecución y modificación del contrato público. Es claro que, en la etapa precontractual, referida al procedimiento de licitación pública para la compra de suministros o servicios, las reglas de nulidad aplicables son extractadas de las leyes 19.880 y 19.886 , reguladoras de las bases de los procedimientos y del contrato administro de suministros, con carácter supletorio se puede acudir al derecho privado. Prevalece el criterio de que los principios de buena fe, seguridad jurídica y derechos adquiridos deben ser reconocidos como limitantes al ejercicio de la facultad anulatoria de la Administración. De este modo, se otorga protección al adjudicatario que no tiene responsabilidad del vicio anulatorio y que legítimamente actúa amparado por el acto de adjudicación. A su vez, en la etapa de ejecución del contrato y respecto de las prórrogas y/o eventuales modificaciones contractuales, la forma compleja en que se perfecciona la "voluntad" de la Administración que además suele ser consignada en las cláusulas contractuales, exige una resolución que apruebe el contrato o la modificación de este, la misma que de no superar el trámite de toma de razón, hace devenir a dicho acto en uno que carece de objeto. En esta circunstancia, no se configura los supuestos de la invalidación por cuanto las obligaciones contraídas en el contrato no han surgido, quedando facultado el servicio para revocar la resolución fallida. La vía para incoar la nulidad del contrato en sede jurisdiccional debe ser la acción especial que corresponda y solo en defecto de no contar con esta es la vía del juicio ordinario la que pueda intentarse.

\section{BIBLIOGRAFÍA}


Acevedo Alvear, Natalia. Licitación pública: regulación y concurrencia. Memoria para optar el grado de Licenciada en Ciencias Jurídicas y Sociales, Santiago, Universidad de Chile, 2015.

Aróstica Maldonado, Iván. "¿Qué queda de la 'presunción de legalidad'?". Revista de Derecho y Jurisprudencia, t. LXXXVIII, n. ${ }^{\circ} 1,1991$.

Bahamondes, Claudia. "La nulidad de los actos administrativos y la nulidad de los actos y contratos del Código Civil: ¿son tan distintas?". Revista Cbilena de Derecho Privado, n. ${ }^{\circ} 8,2007$.

Bernaschina, Mario. "Bases jurisprudenciales para una teoría de las nulidades administrativas". Boletín del Seminario de Derecho Público, n. ${ }^{\circ}$ 45-48, 1949.

Bocksang Hola, Gabriel. "De la imprescriptibilidad de la nulidad de derecho público". Ius Publicum, n. ${ }^{\circ} 14,2005$.

Bocksang Hola, Gabriel. "El ámbito de aplicación de la nulidad de derecho público". En Juan Carlos Ferrada Bórquez (ed.), La nulidad de los actos administrativos en el derecho cbileno. Santiago de Chile: Legal Publishing-Thomson Reuters, 2013.

Camacho Cépeda, Gladys. "El Tribunal de la Contratación Pública en Chile: una década de funcionamiento". En Eloy Espinosa Saldaña (dir.), Tendencias actuales en contratación pública. Lima: Gaceta Jurídica, 2014.

Camacho Cépeda, Gladys. "La eficacia del acto administrativo". Revista de la Facultad de Derecho de México, t. LXIX, n. ${ }^{\circ}$ 274, 2019.

Concha, Ricardo. "El desarrollo del régimen jurídico de la nulidad de derecho público". Revista de Derecho, vol. XXVI, n. ${ }^{\circ} 2,2013$.

Cordero Quinzacara, Eduardo. "Nulidad de derecho público y prescripción", Mercurio Legal, 23 de abril de 2013. Disponible en: https://www.elmercurio.com/Legal/Noticias/Analisis-Juridico/2013/04/23/Nulidad-de-Derecho-Publico-y-Prescripcion. aspx\#: :text=Desde\%20su\%20formulaci\%C3\%B3n\%20inicial\%2C\%20se,una\%20 regla\%20en\%20tal\%20sentido [consultado el 13 de agosto de 2020].

Ferrada Bórquez, Juan Carlos. "Nuevas restricciones a la nulidad de derecho público como proceso administrativo: una jurisprudencia interesante, pero inconsistente". Anuario de Derecbo Público, 2010.

Fiamma, Gustavo. "Acción constitucional de nulidad y legitimación activa objetiva". Revista de Derecho Público, n. ${ }^{\circ}$ 49, 1991.

Garrido Dorn, Carlos. "Ley de Bases de Procedimiento Administrativo y Nulidad de Derecho Público". Revista de Derecho, n. ${ }^{\circ}$ 17, 2007. 
González Pérez, Jesús. "La ley chilena de derecho administrativo". Revista de Administración Pública, n. ${ }^{\circ} 162,2003$.

Guzmán, Alejandro. "La influencia del Código Civil Francés en las codificaciones americanas". Cuadernos de Extensión Jurídica, n. ${ }^{\circ}$ 9, 2004.

Jara Schnettler, Jaime. La nulidad de derecho ante la doctrina y la jurisprudencia. Santiago: Editorial Libro Mar, 2000.

MeILÁn GiL, José Luis. "Intereses generales e interés público desde la perspectiva del derecho público español". A\&C Revista de Direito Administrativo \& Constitucional, n. ${ }^{\circ} 40,2010$.

Mohor Abuauad, Salvador. "Acerca de la nulidad de derecho público en nuestro sistema jurídico constitucional $y$, en especial, de la interpretación armónica de los artículos 6. ${ }^{\circ}$ y 7. ${ }^{\circ}$ de la Constitución". Revista de Derecho Público, n. ${ }^{\circ}$ 76, 2014.

Muñoz Cárdenas, Rodrigo. La nulidad y sus efectos. Causales del Tribunal de Contratación Pública para negar la retroactividad. Memoria para obtener el Grado de Licenciado en Ciencias Jurídicas y Sociales, Santiago, Universidad de Chile, 2017.

Muñoz Machado, Santiago. Vestigios. Madrid: Crítica, 2020.

Pierry Arrau, Pedro. "Nulidad en el derecho administrativo". Revista de Derecho de la Universidad Católica de Valparaíso, n. ${ }^{\circ} \mathrm{XV}$, 1993-1994.

Reyes Riveros, Jorge. La mulidad de derecho público. Santiago: Editorial Conosur, 2000.

Reyes Riveros, Jorge. "Reflexiones acerca de la nulidad de derecho público". Revista de Derecho, n. ${ }^{\circ}$ 4, 2014. Disponible en: http://revistas.uach.cl/html/revider/v4/body/ art07.htm [consultado el 31 de julio de 2020].

Soto Kloss, EduARDo. "La regla de oro del derecho público chileno: sobre los orígenes históricos del artículo 160 de la Constitución de 1883". Anales de la Universidad de Chile, n. ${ }^{\circ}$ 20, 1989, pp. 803-833.

Soto Kloss, Eduardo. "La nulidad de derecho público en el derecho chileno". Revista de Derecho Público, n. ${ }^{\circ} 47 / 48,1990$.

Soto Kloss, Eduardo. "La nulidad de derecho público: su actualidad". Revista de Derecho de la Universidad Católica de Valparaíso, n. ${ }^{\circ}$ XVII, 1997.

Soto Kloss, Eduardo. La regla de oro del derecho público cbileno. Estudios en bonor de Alamiro de Ávila Marte. Santiago: Anales Universidad de Chile, 1989. 